\title{
REALIZACJA PRAWA PETYCJI PRZEZ SEJM VIII KADENCJI (LATA 2015-2018). WYBRANE ZAGADNIENIA
}

\section{REALISATION OF THE RIGHT OF PETITION BY THE SEJM OF THE SEVENTH TERM (2015-2018). SELECTED ISSUES}

The article contains an analysis of the hitherto realisation of the constitutional right of petition by the Sejm of the Republic of Poland. With the entry into force of the Act of 11 July 2014 on petitions, public authorities, including the Sejm, became obliged to consider petitions. In the Sejm, Petition Committee was established as the organ competent to consider petitions submitted to the lower chamber of the parliament. The Committee was appointed at the end of the seventh term of the Sejm, but commenced its substantive activity only at the beginning of the eighth term. Until the end of 2018, Petition Committee altogether considered 393 petitions submitted to the Sejm in the years 2015-2018. In the article such issues are discussed, related to petitions considered by Petition Committee, as: specifying entities exercising the right to petition, the subject of petitions and procedure for considering them. The analysis is based on the materials documenting the works and the course of the sittings of the Sejm Petition Committee during the eighth term, in the years 2015-2018.

Słowa kluczowe: Sejm, petycja, prawo petycji, sejmowa Komisja do Spraw Petycji, ustawa o petycjach

Key words: Sejm, petition, right of petition, Sejm Petition Committee, Act on Petitions

* Dr Zbigniew Gromek, Uniwersytet Warszawski, Wydział Prawa i Administracji, Katedra Prawa Konstytucyjnego, zbigniew.gromek@sejm.gov.pl, https://orcid.org/0000-0003-1873-1998

\section{WPROWADZENIE}

Z godnie z art. 63 zd. 1 Konstytucji RP z dnia 2 kwietnia 1997 r. ${ }^{1}$ każdy ma prawo do składania petycji, wniosków i skarg do organów władzy publicznej, a także do organizacji społecznych w związku z wykonywanymi przez te organizacje zadaniami zleconymi z zakresu administracji publicznej. W kontekście powołanego przepisu nie budzi wątpliwości, że obywatele i podmioty podobne mogą realizować wskazane w nim uprawnienie m.in. poprzez składanie petycji do Sejmu. Statuując prawo petycji, ustrojodawca sprecyzował jednocześnie, że tryb rozpatrywania petycji określa ustawa (art. 63 zd. 2 konstytucji). Delegacja ta została zrealizowana dopiero po upływie 17 lat od wejścia w życie konstytucji, wraz z uchwaleniem ustawy z dnia 11 lipca 2014 r. o petycjach ${ }^{2}$ [dalej: ustawa lub ustawa o petycjach]. Ustawą tą wyznaczono ramy prawne rozpatrywania petycji składanych do organów władzy publicznej, w tym również adresowanych do Sejmu. Wejście ustawy w życie

${ }^{1}$ Dz.U. nr 78, poz. 483, ze zm.

2 Tekst jedn. Dz.U. z 2018 r. poz. 870; ustawa ta weszła w życie 6 września 2015 r. 
zobligowało ostatecznie Sejm do rozpatrywania składanych do tego organu petycji ${ }^{3}$. Zarazem VIII kadencja Sejmu jest pierwszą, w toku której Izba rozpatrywała wnoszone do niej petycje . $^{2}$

Zbliżający się upływ VIII kadencji uzasadnia dokonanie podsumowania dotychczasowych doświadczeń związanych z realizacją przez Sejm obywatelskiego prawa do petycji. Na uwagę zasługują m.in. takie aspekty, jak: przedmiot wnoszonych petycji, podmioty korzystające z prawa petycji do Sejmu, tryb rozpatrywania wnoszonych petycji czy też sposób ich załatwiania przez Sejm. Zgodnie z uchwałą Sejmu RP z dnia 30 lipca 1992 r. — Regulamin Sejmu Rzeczypospolitej Polskiej ${ }^{5}$ [dalej: regulamin Sejmu lub rS] organem właściwym do rozpatrywania petycji wnoszonych do Sejmu jest Komisja do Spraw Petycji [dalej: PET lub Komisja]. Stosownie do tego poddano analizie prace tej Komisji w okresie VIII kadencji Sejmu (lata 2015-2018), na podstawie stenogramów z posiedzeń Komisji oraz sporządzanych przez nią informacji rocznych nt. rozpatrzonych petycji ${ }^{6}$. $Z$ uwagi na ramy prezentowanego artykułu podjęto $\mathrm{w}$ nim jedynie najważniejsze aspekty związane z działalnością PET i problematyką petycji wnoszonych do Sejmu. Zagadnienie to zasługuje na dalsze, bardziej pogłębione badania ${ }^{7}$.

\section{PODMIOTY SKLADAJĄCE PETYCJE DO SEJMU}

1. W przepisach prawnych kwestia podmiotów uprawnionych do wnoszenia petycji została określona w sposób bardzo ogólny. Podstawowe znaczenie ma w tym zakresie art. 63 zd. 1 konstytucji, zgodnie z którym prawo to przysługuje „każdemu”. Przepis ten nie może być jednak odczytywany jako przyznający możliwość złożenia petycji dowolnym podmiotom w państwie. Prawo petycji stanowi jedno z konstytucyjnych wolności i praw, których adresatami są przede wszystkim obywatele ${ }^{8}$,

${ }^{3}$ Trzeba zauważyć, że brak regulacji ustawowej nie stanowił przeszkody w rozpatrywania petycji przez Senat (od 2009 r.) w ramach senackiej Komisji Praw Człowieka, Praworządności i Petycji.

${ }^{4}$ Wprawdzie jeszcze pod koniec VII kadencji Sejm powołał Komisję do Spraw Petycji, jednak odbyła ona tylko dwa posiedzenia, w tym jedno o charakterze organizacyjnym. Komisja działająca w VII kadencji przystąpiła do rozpatrzenia jednej petycji, ale nie podjęła żadnego rozstrzygnięcia. Wszystkie petycje wniesione do Sejmu VII kadencji zostały przekazane do Komisji do Spraw Petycji działającej w VIII kadencji.

${ }^{5}$ Tekst jedn. M.P. z 2012 r. poz. 32, ze zm.

${ }^{6}$ Materiały te są dostępne na stronie internetowej Sejmu <https://www.sejm.gov.pl>, dostęp 31 XII 2018.

${ }^{7}$ Problematyka ta stanowiła już zresztą przedmiot zainteresowania przedstawicieli doktryny; vide np. E. Gierach, P. Chybalski, Postepowanie w sprawie petycji w Sejmie - prawo i praktyka, [w:] Skargi, wnioski i petycje - powszechne środki ochrony prawnej, red. M. Błachucki, G. Sibiga, Wrocław 2017, s. $453-476$.

${ }^{8} \mathrm{~W}$ piśmiennictwie sprzed wejścia w życie ustawy o petycjach prezentowany był pogląd, zgodnie z którym prawo petycji ma charakter kolegialny i przysługuje grupie obywateli, a nie poszczególnym jednostkom (confer np. K. Działocha, Prawo petycji w obowiazujacym ustawodawstwie i proponowane kierunki zmian, [w:] Prawo petycji w ustawodawstwie polskim, „Opinie i Ekspertyzy” 2008, nr 85, s. 3; W. Orłowski, Konstytucyjne uwarunkowania prawa petycji, [w:] Prawo petycji w ustawodawstwie polskim, „Opinie i Ekspertyzy” 2008, nr 85, s. 11; P. Sarnecki, Prawo konstytucyjne RP, Warszawa 2014, s. 150). Zgodnie z art. 2 ust. 1 ustawy o petycjach („Petycja może być złożona przez osobę fizyczną”) nie budzi jednak wątpliwości, że prawo petycji jest uprawnieniem indywidualnym, przysługującym pojedynczym osobom. Nie wyklucza to oczywiście złożenia petycji przez większą liczbę osób. 
jak również cudzoziemcy przebywający pod władzą państwa polskiego. $\mathrm{Na}$ równi z obywatelami prawo do wnoszenia petycji przysługuje strukturom tworzonym przez obywateli, do których zaliczają się: stowarzyszenia, fundacje, spółki, organizacje pracodawców, organizacje pracowników, kościoły i związki wyznaniowe itp. Podmioty te są — w zakresie uwzględniającym ich specyfikę - nosicielami konstytucyjnych wolności i praw, a więc także prawa do petycji. Kategoria konstytucyjnych wolności i praw nie ma natomiast zastosowania w odniesieniu do podmiotów o charakterze publicznym, w tym zwłaszcza do organów władzy publicznej, innych państw itp. ${ }^{9}$ Tym samym nie przysługuje im uprawnienie do wnoszenia petycji.

Na podstawie złożonych w Sejmie VIII kadencji petycji można wymienić następujące kategorie podmiotów, które - w analizowanym okresie — korzystały z prawa petycji. Są to: osoby fizyczne, stowarzyszenia (w tym stowarzyszenia jednostek samorządu terytorialnego), fundacje, partie polityczne, spółki prawa handlowego, organizacje pracodawców, samorządy zawodowe, związki zawodowe, organy jednostek samorządu terytorialnego. Wyliczenie to nie jest wyczerpujące, ponieważ incydentalnie petycje wnosiły także podmioty, które nie zaliczają się do żadnej z wyróżnionych kategorii (m.in. samorząd uczniowski, spółdzielnia mieszkaniowa).

Dominującymi ilościowo podmiotami występującymi z petycjami były osoby fizyczne: w 2015 r. złożyły one pięć petycji (na 26 petycji złożonych ogółem), w 2016 r. - 81 petycji (na 134 petycji ogółem), w 2017 r. - 118 petycji (na 155 petycji ogółem). W 2018 r. tendencja ta utrzymała się ${ }^{10}$. W odniesieniu do petycji wnoszonych przez osoby fizyczne warto zauważyć, że uprawnienie to mogą realizować nie tylko pełnoletni obywatele polscy, ale także - co potwierdza praktyka działalności Komisji - osoby małoletnie ${ }^{11}$ oraz cudzoziemcy ${ }^{12}$. Kolejną co do częstotliwości kategorią podmiotów korzystającą z prawa petycji w analizowanym okresie były stowarzyszenia ${ }^{13}$.

Zgodnie z ustawą podmiot występujący z petycją może zastrzec nieujawnianie swoich danych personalnych (art. 4 ust. 3). W takim przypadku informacje te nie są udostępniane $\mathrm{w}$ materiałach dokumentujących prace komisji (biuletyny z posiedzeń, informacje roczne), a dane osobowe zawarte w publikowanych na stronie internetowej Sejmu petycjach są zanonimizowane. Rozwiązaniu temu należy w pierwszej kolejności

9 Confer M. Masternak-Kubiak, P. Kuczma, Prawo petycji jako publiczne prawo podmiotowe (aspekt podmiotowy i przedmiotowy), [w:] Teoretyczne i praktyczne aspekty realizacji prawa petycji, red. R. Balicki, M. Jabłoński, Wrocław 2015, s. 271-272; S. Gajewski, A. Jakubowski, Petycje, skargi $i$ wnioski. Dziat VIII Kodeksu postępowania administracyjnego. Ustawa o petycjach. Komentarz, Warszawa 2015, s. 145 .

${ }^{10}$ Dane dotyczące podmiotów występujących z petycjami są publikowane zbiorczo w informacji rocznej o złożonych petycjach. W trakcie prac nad niniejszym artykułem informacja za rok 2018 nie została jeszcze opublikowana.

11 Confer petycja BKSP-145-83/16.

12 Confer petycja BKSP-145-109/16.

${ }_{13}$ Confer szczegółowe dane zawarte w informacjach o rozpatrzonych petycjach za lata 2015, 2016 i 2017. 
przypisać charakter gwarancyjny, zapewniający realizację zasady wyrażonej w art. 225 $\S 1$ ustawy z dnia 14 czerwca $1960 \mathrm{r}$. — Kodeks postępowania administracyjnego ${ }^{14}$, zgodnie z którym nikt nie może być narażony na jakikolwiek uszczerbek lub zarzut z powodu złożenia skargi lub wniosku albo z powodu dostarczenia materiału do publikacji o znamionach skargi lub wniosku, jeżeli działał w granicach dozwolonych prawem.

2. Elementem charakteryzującym wykonywanie prawa petycji w VIII kadencji Sejmu jest to, że niektóre podmioty korzystały z omawianego uprawnienia wielokrotnie. Co najmniej 25 podmiotów wniosło do Sejmu więcej niż jedną petycję, z czego w dziewięciu przypadkach ten sam podmiot wystąpił co najmniej z pięcioma petycjami. W odniesieniu do osób fizycznych największa liczba petycji wniesionych przez tę samą osobę wynosi 35 (i kolejno: 33, 16, 10, 9 i 9). Dane te wskazują, że sześć osób fizycznych wystąpiło łącznie ze 112 petycjami, co stanowi niemal 1/4 ogółu liczby petycji wniesionych $w$ analizowanym okresie. $Z$ tego dwie najbardziej aktywne w tym względzie osoby złożyły łącznie 68 petycji, a więc ponad 15\% ogółu petycji. Również w odniesieniu do podmiotów innych niż osoby fizyczne trzeba odnotować zjawisko wielokrotnego występowania z petycjami przez ten sam podmiot. Największa liczba petycji wniesionych przez jeden podmiot niebędący osobą fizyczną wynosi kolejno: 14, 6, 6 i 5 petycji (podmiotami występującymi w tym przypadku z petycjami były odpowiednio: stowarzyszenie, dwie fundacje oraz partia polityczna).

Na tym tle może pojawić się wątpliwość, czy wielokrotne występowanie przez ten sam podmiot $\mathrm{z}$ petycjami $\mathrm{w}$ różnych sprawach nie stanowi w pewnym stopniu nadużycia prawa petycji ${ }^{15}$. Odpowiadając na tak postawione pytanie, trzeba wskazać, że art. 63 konstytucji nie ogranicza w żaden sposób warunków wykonywania prawa petycji. Przepis ten dopuszcza przy tym expressis verbis występowanie z petycjami w interesie publicznym, po stronie podmiotu występującego z petycją nie musi zatem istnieć jakikolwiek interes (prawny, faktyczny) uzasadniający jej wniesienie. $Z$ tego względu wielokrotne występowanie przez ten sam podmiot $\mathrm{z}$ różnymi petycjami, choćby organ nie uznawał ich zasadności, nie może być uznawane za nadużycie omawianego uprawnienia $^{16}$. Natomiast sytuacja, w której ta sama osoba występuje kolejno z szeregiem petycji dotyczących $\mathrm{w}$ istocie podobnych przedmiotowo spraw, stanowi niewątpliwie pewne obciążenie dla organu będącego adresatem petycji, w tym również dla $\mathrm{PET}^{17}$.

14 Tekst jedn. Dz.U. z 2018 r. poz. 2096, ze zm.

15 Nierzadkie są przy tym sytuacje, w których ten sam podmiot występuje z taką samą petycją również do innych niż Sejm organów państwa (Senatu, prezesa Rady Ministrów, ministrów itd.).

16 Warto zauważyć, że w piśmiennictwie wymienia się sytuacje, w których wystąpienie z petycją mogłoby być jednak uznane za nadużycie prawa (confer A. Piskorz-Ryń, J. Wyporska-Frankiewicz, Wykorzystywanie prawa do petycji w sposób niezgodny z jego celem. Zagadnienia wybrane, [w:] Skargi, wnioski i petycje..., s. 440-449).

17 Przykładowo jeden z podmiotów złożył do Sejmu kilka odrębnych petycji dotyczących uaktualnienia pojęć występujących w poszczególnych ustawach (np. zastąpienia pojęcia „sąd wojewódzki” pojęciem ,sąd okręgowy”). 
3. W praktyce działalności PET za podmiot uprawniony do występowania z petycją uznano m.in. organy samorządu terytorialnego ${ }^{18}$. Stanowisko to nie może jednak zostać uznać za trafne. Jak już wskazywano, mimo posłużenia się przez ustrojodawcę sformułowaniem „każdy” na oznaczenie podmiotu uprawnionego do wystąpienia z petycją, pojęcie to należy zawęzić wyłącznie do podmiotów konstytucyjnych wolności i praw. Do tego kręgu nie zaliczają się podmioty o charakterze państwowym, powołane do sprawowania władzy publicznej w formach typowych dla państwa, a więc z wykorzystaniem imperium ${ }^{19}$. Status jednostek samorządu terytorialnego stanowi przedmiot odrębnej regulacji w konstytucji (rozdział VII), co także stanowi argument na rzecz uznania, że podmioty te nie są adresatami konstytucyjnych wolności i praw, w tym prawa petycji. W konsekwencji marszałek Sejmu powinien odmawiać nadania biegu petycjom złożonym przez organy samorządu terytorialnego, podobnie jak i petycjom wnoszonym przez organy samorządu zawodowego. Za błędną należy również uznać interpretację, wedle której petycje składane przez organy samorządu terytorialnego miałyby być petycjami wnoszonymi w imieniu i na rzecz mieszkańców, a więc szczególną formą petycji składaną w imieniu innych osób (in concreto — członków wspólnoty samorządowej) ${ }^{20}$.

Sceptycznie trzeba odnieść się do wykorzystywania instytucji petycji przez partie polityczne ${ }^{21}$. Partia polityczna jest wprawdzie adresatem co najmniej niektórych konstytucyjnych wolności i praw, do których zalicza się m.in. prawo petycji. Formalnie zatem petycja wniesiona do Sejmu przez partię polityczną jest w pełni dopuszczalna i podlega rozpatrzeniu przez PET na równi z petycjami wnoszonymi przez obywateli, stowarzyszenia, fundacje itd. Należy jednak wyrazić pogląd, że w celu inicjowania zmian ustawodawczych partie polityczne reprezentowane w Sejmie powinny korzystać przede wszystkim z poselskiego prawa inicjatywy ustawodawczej. Natomiast w przypadku partii nieposiadających reprezentacji w Sejmie za właściwy tryb podejmowania tego typu inicjatyw trzeba uznać obywatelską inicjatywę ustawodawczą.

${ }^{18}$ Początkowo występowanie z petycjami przez podmioty o charakterze samorządowym nie budziło wątpliwości Komisji. W późniejszym okresie zaczęto kwestionować legitymację organów samorządu terytorialnego do występowania z petycjami (confer przebieg posiedzenia komisji z 5 kwietnia 2017 r.). Mimo to w późniejszym okresie Komisja nadal rozpatrywała petycje wnoszone przez organy samorządu terytorialnego (np. petycja BKSP-145-363/18). Kwestia ta nie jest jednolicie oceniana w literaturze, choć dominuje stanowisko, zgodnie z którym organom samorządu terytorialnego nie przysługuje prawo do występowania z petycjami (confer A. Rytel-Warzocha, Instytucja petycji w Polsce oraz w krajach europejskich - stan obecny i perspektywy, „Opinie i Analizy” OE-238, Kancelaria Senatu, Warszawa 2015, s. 14; P. Czarny, Opinia prawna w sprawie dopuszczalności składania petycji przez jednostki samorzadu terytorialnego, „Zeszyty Prawnicze BAS” 2017, nr 3, s. 63-67; J. Galster, D. Lis-Staranowicz, Zakres podmiotowy prawa do petycji w Polsce i w Unii Europejskiej. Przyczynek do dyskusji, „Przegląd Sejmowy" 2018, nr 3, s. 66-69).

${ }^{19}$ Confer analogicznie J. Rzucidło, Prawo petycji w dziatalności Senatu i Sejmu RP w latach 2010-2015, [w:] Teoretyczne i praktyczne aspekty realizacji prawa petycji..., s. 375.

20 Vide posiedzenia komisji z 9 marca 2017 r. oraz 22 marca 2017 r.

${ }^{21} \mathrm{~W}$ okresie objętym analizą ogółem sześć petycji zostało złożonych przez partie polityczne, przy czym pięć petycji pochodziło od tej samej partii. 


\section{PRZEDMIOT PETYCJI SKŁADANYCH DO SEJMU}

1. Dopuszczalny zakres przedmiotowy petycji wyznaczają kompetencje organu, do którego adresowana jest petycja ${ }^{22}$. Tym samym do Sejmu może zostać wniesiona petycja wzywająca ten organ do podjęcia różnego rodzaju działań, o ile mieszczą się one w zakresie jego kompetencji. Należy do nich zaliczyć m.in. petycje postulujące uchwalenie ustawy o określonej treści, zlecenie przeprowadzenia kontroli przez Najwyższą Izbę Kontroli, zarządzenie referendum ogólnokrajowego. Wątpliwości powstają natomiast $\mathrm{w}$ kwestii dopuszczalności wystąpienia $\mathrm{z}$ petycją $\mathrm{w}$ sprawach mieszczących się wprawdzie w kompetencjach Sejmu, ale podejmowanych przez ten organ na wniosek grupy posłów (np. wyrażenie ministrowi wotum nieufności) ${ }^{23}$ czy też podmiotów zewnętrznych.

Prawodawca nie limituje liczby spraw objętych petycją, może ona zatem dotyczyć jednej bądź więcej spraw. W tym ostatnim przypadku na adresacie petycji ciąży obowiązek rozpatrzenia wszystkich spraw stanowiących jej przedmiot.

Zdecydowana większość petycji wnoszonych do Sejmu VIII kadencji zawierała postulat dokonania zmian w obowiązującym prawie, polegających na dodaniu nowych przepisów, zmianie brzmienia istniejących lub ich uchyleniu. Wymaga podkreślenia, że petycje adresowane do Sejmu mogą dotyczyć — ze względu na zakres kompetencji prawodawczych przysługujących temu organowi - wyłącznie zmian w ustawach bądź w konstytucji. Rozpatrywanie petycji dotyczących zmian w innych aktach normatywnych, w szczególności w rozporządzeniach, nie leży natomiast w gestii Sejmu. W przypadku wniesienia do Sejmu takiej petycji Komisja powinna ją przekazać do organu właściwego do jej rozpatrzenia, a więc organu, który wydał dany akt.

W ustawie o petycjach nie rozstrzygnięto, czy przedmiotem petycji skierowanej do Sejmu może być propozycja zmiany ustawy, w odniesieniu do której w konstytucji przewidziano wyłączną inicjatywę ustawodawczą na rzecz Rady Ministrów²4. Wydaje się, że w tym przypadku petycja powinna zostać uznana za niedopuszczalną. PET nie jest bowiem kompetentna w zakresie ewentualnego uwzględnienia tej petycji — nie przysługuje jej uprawnienie do wystąpienia z projektem ustawy w danej materii, skoro zostało ono zastrzeżone na rzecz innego podmiotu (Rady Ministrów).

${ }^{22}$ W kwestii zakresu przedmiotowego prawa do petycji confer m.in. M. Florczak-Wątor, komentarz do art. 63, [w:] Konstytucja RP. Komentarz, t. I, art. 1-86, red. M. Safjan, L. Bosek, Warszawa 2016, s. $1452-1455$.

${ }^{23}$ Należy przyjąć, że przedmiotem petycji kierowanej do Sejmu może być postulat podjęcia przez tę Izbę określonego rozstrzygnięcia w sprawie wotum nieufności, o ile wniosek w tej sprawie został już wniesiony przez grupę posłów. Celowość wniesienia takiej petycji wydaje się jednak dyskusyjna.

${ }^{24}$ Warto zauważyć, że kwestia ta została uregulowana w przypadku obywatelskiej inicjatywy ustawodawczej. Zgodnie z art. 3 ustawy z dnia 24 czerwca 1999 r. o wykonywaniu inicjatywy ustawodawczej przez obywateli (tekst jedn. Dz.U. z 2018 r. poz. 2120), projekt ustawy wnoszony przez grupę co najmniej 100 tys. obywateli nie może dotyczyć spraw, w odniesieniu do których w Konstytucji Rzeczypospolitej Polskiej zastrzeżono wyłączną właściwość innych podmiotów, którym przysługuje inicjatywa ustawodawcza. 
Podobna sytuacja dotyczy petycji zawierającej postulat zmiany konstytucji, jako że Komisji nie przysługuje inicjatywa ustrojodawcza ${ }^{25}$.

Incydentalny charakter miały petycje, w których domagano się podjęcia przez Sejm innych działań niż zmiana obowiązujących ustaw. W tym kontekście należy wymienić petycje zawierające żądanie podjęcia uchwały mającej charakter rezolu$\mathrm{cji}^{26}$, zarządzenia referendum ogólnokrajowego ${ }^{27}$ oraz powołania komisji nadzwyczajnej $^{28}$. Ponadto do PET została skierowana - w celu wyrażenia opinii - petycja w sprawie odwołania organu powołanego przez Sejm ${ }^{29}$.

$\mathrm{W}$ art. 63 zd. 1 konstytucji dopuszczono wnoszenie petycji w interesie publicznym, własnym lub innej osoby. Analogicznie sprawa ta została uregulowana w art. 2 ust. 2-3 ustawy o petycjach. Wobec tak szerokiego określenia interesu (prawnego, faktycznego) podmiotu wnoszącego petycję, nawiązującego do koncepcji actio popularis, przesłanka wystąpienia tego interesu nie jest badana w toku rozpatrywania petycji przez PET.

2. Zróżnicowanie materii, których dotyczą petycje wnoszone do Sejmu, jest bardzo szerokie. Statystycznie najliczniej składano petycje dotyczące wprowadzenia zmian w ustawach z zakresu pomocy społecznej i świadczeń socjalnych, uprawnień emerytalnych i rentowanych oraz praw osób niepełnosprawnych ${ }^{30}$. Trzeba również odnotować, że niemała część petycji była ukierunkowana na zmianę przepisów dotyczących konkretnych środowisk (osoby niesłyszące, funkcjonariusze Służby Celnej) czy też problemów dotyczących określonych podmiotów (np. opieka nad dziećmi rozwiedzionych rodziców).

W zdecydowanej większości petycje zawierały propozycje wprowadzenia jednostkowych zmian w obowiązujących ustawach, obejmujących jeden bądź kilka powiązanych ze sobą przepisów. Przy tym większość petycji dotyczyła zmian o drobnym charakterze, które nie miały zasadniczego znaczenia dla danej dziedziny spraw poddanych regulacji prawnej. Trzeba równocześnie wskazać, że w niektórych petycjach zawarto postulaty zmian o istotnym znaczeniu dla danej sfery stosunków społecznych, a nawet podjęcia nowelizacji o charakterze systemowym czy ustrojowym. W tym kontekście można wymienić petycje dotyczące: zasad działania sądów i wyboru sędziów ${ }^{31}$;

${ }^{25}$ Nie oznacza to jednak, że petycje tego rodzaju nie mogą być wnoszone do Sejmu. Skoro uchwalenie ustawy o zmianie konstytucji mieści się w kompetencjach Sejmu, to tej materii może również dotyczyć petycja. Komisja, uznając zasadność takiej petycji, nie mogłaby jednak jej zrealizować, skoro nie przysługuje jej inicjatywa ustrojodawcza. Można rozważyć, czy nie byłoby zasadne przekazanie rozpatrywania tego typu petycji Sejmowi in gremio.

${ }^{26}$ Confer m.in. petycje BKSP-145-109/16; BKSP-145-191/17 i BKSP-145-330/18.

27 Confer m.in. petycje BKSP-145-121/16 i BKSP-145-364/18.

28 Confer petycja BKSP-145-164/16.

${ }^{29}$ Confer posiedzenie Komisji z 25 listopada 2017 r. Komisja uznała, że nie jest właściwym organem do wyrażenia opinii w sprawie tej petycji.

${ }^{30}$ Szczegółowe zestawienie materii, w których wnoszone były petycje, zawierają informacje roczne o wniesionych petycjach.

31 Petycja BKSP-145-224/17. 
zniesienia habilitacji32; podwyższenia progów wyborczych w wyborach do Sejmu ${ }^{33}$; wprowadzenia obowiązku głosowania w wyborach powszechnych ${ }^{34}$; likwidacji składki na Narodowy Fundusz Zdrowia i objęcia obywateli opieką zdrowotną finansowaną ze środków publicznych ${ }^{35}$; ochrony płodu ludzkiego i warunków przerywania ciąży ${ }^{36}$; wprowadzenia związków partnerskich ${ }^{37}$; podwyższenia wieku emerytalnego ${ }^{38}$; utworzenia nowego województwa ${ }^{39}$.

Uwzględniając zróżnicowany ciężar gatunkowy postulatów zawartych w poszczególnych petycjach, w trakcie prac PET wielokrotnie wyrażano stanowisko, że jej aktywność legislacyjna powinna mieć charakter uzupełniający względem pozostałych podmiotów wyposażonych w inicjatywę ustawodawczą. Komisja powinna zatem podejmować inicjatywę ustawodawczą w sprawach niemających istotnego znaczenia dla danej dziedziny stosunków społecznych, regulowanych w pojedynczych przepisach, przy czym zasadność wprowadzenia tych zmian nie może budzić wątpliwości ${ }^{40}$. W konsekwencji odmawiano uwzględnienia petycji, które zawierały postulaty zmian o charakterze systemowym, jako niemieszczących się w profilu działalności PET.

$Z$ jednej strony trzeba wyrazić wątpliwość, czy przedstawione podejście nie stanowi swoistego ograniczenia prawa do petycji. Komisja z góry wyłączyła bowiem ze swoich prac określoną kategorię spraw (sprawy kompleksowe, o dużym stopniu złożoności, budzące spory polityczne itd.). $\mathrm{Z}$ drugiej jednak strony nie można nie dostrzegać, że inicjatywy tego typu leżą przede wszystkim w gestii innych podmiotów wyposażonych w inicjatywę ustawodawczą, do których zalicza się m.in. grupa co najmniej 100 tys. obywateli. Wnoszenie petycji nie powinno jednak stanowić alternatywy (czy zwłaszcza uproszczonego trybu) dla obywatelskiej inicjatywy ustawodawczej. Komisja - co do zasady — nie powinna również podejmować inicjatywy ustawodawczej zmierzającej do wprowadzenia zmian $\mathrm{w}$ dopiero co uchwalonych ustawach, jeżeli dana sprawa stanowiła przedmiot pogłębionej debaty (a zwłaszcza sporów) i Sejm świadomie przyjął rozwiązanie odmienne niż postulowane przez autora (autorów) petycji.

32 Petycja BKSP-145-11/15.

${ }^{33}$ Petycja BKSP-145-124/16.

${ }^{34}$ Petycja BKSP-145-269/17.

${ }_{35}$ Petycja BKSP-145-100/16.

${ }_{36}$ Petycja BKSP-146-141/16.

${ }^{37}$ Petycja BKSP-145-243/17.

${ }^{38}$ Petycja BKSP-145-332/18.

${ }^{39}$ Petycja BKSP-145-380/18.

40 Confer m.in. wypowiedzi posłów na posiedzeniach komisji z: 10 marca 2016 r., 9 czerwca 2016 r., 22 lutego 2017 r., 7 marca 2017 r., 7 czerwca 2018 r. i 20 czerwca 2018 r. Trzeba też odnotować stanowisko przewodniczącego Komisji wyrażone na posiedzeniu z 12 kwietnia 2016 r., zgodnie z którym przedmiotem inicjatywy Komisji powinny być sprawy „zamknięte, ograniczone i konkretne”, natomiast Komisja nie powinna podejmować spraw, które „dawałyby impuls do debaty o fundamentalnym znaczeniu dla państwa". Analogiczne stanowisko zostało wyrażone w odniesieniu do zmian legislacyjnych w materiach odznaczających się specjalistycznym charakterem (confer posiedzenie komisji z 17 lipca 2018 r.). 


\section{WYMOGI FORMALNE PETYCJI}

Wymogi formalne dotyczące petycji określono w art. 4 ust. 1 i ust. 2 ustawy o petycjach. Petycja powinna zawierać oznaczenie podmiotu wnoszącego petycję, jak również wskazanie miejsca jego zamieszkania (siedziby) oraz adres do korespondencji. Ponadto skuteczność wniesienia petycji została uzależniona od dochowania formy określonej w ustawie, a więc formy pisemnej bądź elektronicznej. Wyklucza to wniesienie petycji $\mathrm{w}$ formie ustnej.

W ustawie nie sprecyzowano wymogów dotyczących sposobu sformułowania petycji. Jeżeli uwzględnić, że zdecydowana większość petycji kierowanych do Sejmu zawiera żądanie zmiany przepisów prawnych, oznacza to, że wystarczające jest, aby autor w sposób ogólny opisał postulowany stan prawny w danej dziedzinie. Nie jest natomiast konieczne wskazanie brzmienia proponowanych przepisów. Sformułowanie przez podmiot wnoszący petycję konkretnych propozycji legislacyjnych jest jednak niewątpliwym ułatwieniem dla PET, także w kwestii właściwego odczytania rzeczywistych intencji podmiotu występującego z petycją.

Analogiczne uwagi można odnieść do kwestii uzasadnienia postulatów zawartych w petycji. Przepisami ustawy na wnoszącego petycję nie nałożono obowiązku jej uzasadnienia, niemniej jego brak bądź daleko posunięta ogólnikowość znacząco zmniejsza szanse na jej uwzględnienie. W takiej sytuacji PET nie dysponuje bowiem argumentami dotyczącymi w szczególności celów, jakie ma realizować postulowana zmiana przepisów prawa. Jeżeli autor petycji zdecydował się na uzasadnienie sformułowanych w niej postulatów, to nie musi ono zawierać elementów wymaganych w przypadku uzasadnień do projektów ustaw. Stąd też wnoszący petycję nie jest zobowiązany do wskazania skutków finansowych wynikających z proponowanych zmian (confer art. 118 ust. 3 konstytucji, zgodnie z którym podmiot wnoszący projekt ustawy jest zobowiązany do przedstawienia skutków finansowych jej wykonania). Uzasadnienie nie musi także spełniać szczegółowych wymogów dotyczących uzasadnienia do projektu ustawy, określonych $\mathrm{w}$ art. 34 ust. 2 i ust. $3 \mathrm{rS}$. Autor petycji może natomiast zrealizować te wymogi (niektóre bądź wszystkie).

\section{SPOSÓB ROZPATRZENIA PETYCJI PRZEZ KOMISJE DO SPRAW PETYCJI}

1. Organ, do którego została wniesiona petycja, jest zobowiązany do jej rozpatrzenia. Uwzględnienie przez organ żądania zawartego w petycji ma natomiast charakter dyskrecjonalny ${ }^{41}$. Oznacza to, że PET nie ma obowiązku uwzględnienia wniesionej petycji także w sytuacji, gdy zawarte w niej propozycje zasługują — biorąc pod uwagę obiektywne okoliczności - na aprobatę ${ }^{42}$.

${ }^{41}$ Brak związania organu treścią wniesionej petycji stanowi niekwestionowany element charakteryzujący prawo petycji (vide np. E. Wójcicka, Prawo petycji w Rzeczypospolitej Polskiej, Warszawa 2015, s. 147).

${ }^{42} \mathrm{Z}$ tego względu nie można zgodzić się ze stanowiskiem, zgodnie z którym w razie stwierdzenia przez organ będący adresatem petycji słuszności zawartego w niej żądania, organ ten jest zobowiązany do podjęcia czynności niezbędnych do jego uwzględnienia (vide M. Ożóg, Uregulowanie instytucji petycji w ustawie z dnia 11 lipca 2014 r. o petycjach, „Przegląd Sejmowy” 2015, nr 5, s. 138-139). 
Obok pojęcia „rozpatrzenie petycji” ustawodawca posłużył się także pojęciem „załatwienie petycji”43, przy czym treść tego ostatniego nie została bliżej wyjaśniona. Regulacja zawarta w ustawie o petycjach nakazuje przyjąć, że po rozpatrzeniu petycji organ „załatwia” tę petycję, co wyraża się w jej uwzględnieniu bądź nieuwzględnieniu. Pod pojęciem ,uwzględnienie petycji” należy rozumieć podjęcie przez organ, do którego petycja została skierowana, działań w niej wskazanych, o ile mieszczą się one w zakresie właściwości adresata petycji. Ustawodawca wymienił przy tym przykładowe działania polegające na uwzględnieniu petycji, zaliczając do nich m.in. „zmianę przepisów prawa". Oznacza to, że w przypadku Sejmu uwzględnienie petycji wyraża się w szczególności w uchwaleniu ustawy (ustaw) obejmujących zmiany normatywne postulowane w petycji. Ponadto petycje mogą być kierowane także we wszelkich pozostałych sprawach mieszczących się w kompetencjach Sejmu, a więc przykładowo w sprawie zarządzenia ogólnokrajowego referendum. Uwzględniając taką petycję, Sejm powinien zatem podjąć wskazane w niej czynności (a więc np. zarządzić referendum). Nieuwzględnienie petycji odnosi się zaś do sytuacji, w której organ po rozpatrzeniu petycji stwierdził brak zasadności podjęcia wskazanych w niej działań.

Sposób załatwienia petycji kierowanych do Sejmu został bardziej skonkretyzowany w art. 126c ust. 3 rS. Wymieniono w nim następujące działania, które PET może podjąć po rozpatrzeniu petycji: 1) wniesienie projektu ustawy lub uchwały; 2) wniesienie poprawki lub wniosku do projektu ustawy lub uchwały w czasie jego rozpatrywania przez inną komisję sejmową lub w czasie jego drugiego czytania; 3 ) przedstawienie innej komisji sejmowej opinii w sprawie rozpatrywanego przez nią projektu ustawy lub uchwały; 4) wystąpienie z wnioskiem o przeprowadzenie kontroli przez Najwyższą Izbę Kontroli; 5) nieuwzględnienie żądania będącego przedmiotem petycji. Brzmienie art. 126c ust. 3 rS („w szczególności”) przesądza o tym, że zawarty w nim katalog działań podejmowanych przez PET ma charakter otwarty ${ }^{44}$. Dopuszczalnym sposobem rozstrzygnięcia w sprawie petycji jest ponadto przekazanie jej do rozpatrzenia innemu organowi, jeżeli petycja nie dotyczy spraw mieszczących się w zakresie kompetencji Sejmu. Taki tryb postępowania przewidziano w art. 6 ust. 1 ustawy o petycjach. Niewymienienie tego działania w katalogu zawartym w art. 126 ust. $3 \mathrm{rS}$ nie stanowi tym samym przeszkody dla podjęcia przez PET uchwały dotyczącej przekazania petycji właściwemu organowi ${ }^{45}$.

Najczęstszym sposobem załatwienia petycji przez PET w toku VIII kadencji Sejmu było nieuwzględnienie żądania zawartego w petycji. W większości przypadków powodem przyjęcia takiego rozstrzygnięcia było stanowisko Komisji, że postulowana

43 Vide art. 8 ust. 2 i art. 13 ust. 1 ustawy. Co najmniej w części przypadków pojęcie ,załatwienie petycji” pokrywa się w pojęciem ,rozpatrzenie petycji”.

44 Jeżeli rozstrzygnięcie co do sposobu załatwienia petycji ma jednak polegać na podjęciu działania innego niż wymienione expressis verbis w art. 126c ust. 3 rS, to mogą to być wyłącznie czynności mieszczące się w zakresie działania stałych komisji sejmowych (np. wystąpienie z dezyderatem).

${ }^{4} \mathrm{Za}$ nietrafne należy uznać stanowisko wyrażone w tym względzie na posiedzeniu komisji z 30 marca 2016 r. i 27 kwietnia 2016 r., kiedy to komisja ds. petycji uznała się za nieuprawnioną do przekazania petycji innemu organowi. 
zmiana jest niecelowa bądź też nie występują okoliczności przemawiające za jej zasadnością. W niektórych sytuacjach o przyjęciu takiego sposobu załatwienia petycji przesądziła z kolei okoliczność, że w postulowanej sprawie zostało już wszczęte postępowanie ustawodawcze bądź też że Rada Ministrów planuje w bliskiej perspektywie czasowej wystąpić z taką inicjatywą ${ }^{46}$. Wreszcie istotną przesłanką przesądzającą o braku podstaw do podjęcia sprawy postulowanej w petycji był szeroki (systemowy) zakres proponowanych zmian.

Kolejnym co do częstotliwości rozstrzygnięciem podejmowanym przez PET w sprawie petycji było wystąpienie z dezyderatem do organów administracji rządowej ${ }^{47}$ o przedstawienie informacji w sprawie objętej petycją. Po otrzymaniu odpowiedzi na dezyderat Komisja rozpatrywała ją w trybie określonym w art. 159 ust. 5 rS. W zdecydowanej większości przypadków, po rozpatrzeniu odpowiedzi na dezyderat Komisja stwierdzała, że nie uwzględnia petycji. Znacznie mniejszy był odsetek spraw, w których po rozpatrzeniu odpowiedzi na dezyderat Komisja postanawiała jednocześnie podjąć inicjatywę ustawodawczą. Odnotować trzeba także przypadki, w których Komisja uznawała odpowiedź na dezyderat za niezadowalającą i występowała o jej uzupełnienie.

Wykorzystywanie przez PET uprawnienia do występowania z dezyderatami nadaje działalności tej Komisji szczególny rys na tle pozostałych komisji sejmowych. I tak w trakcie VIII kadencji (do 31 grudnia 2018 r.) stałe komisje sejmowe ${ }^{48}$ wystąpiły łącznie z 208 dezyderatami, z czego Komisja do Spraw Petycji uchwaliła aż 134 dezyderaty. Przy tym żadna z pozostałych komisji sejmowych nie wystąpiła w analizowanym okresie $\mathrm{z}$ więcej niż dziewięcioma dezyderatami, a część komisji w ogóle nie uchwaliła żadnego dezyderatu ${ }^{49}$.

Dezyderaty uchwalane przez PET w istotny sposób wykraczają poza typową funkcję przypisywaną tej kategorii uchwał. Zgodnie z art. 159 ust. $1 \mathrm{rS}$ dezyderat stanowi instrument kontroli przysługujący komisjom sejmowym, umożliwiający wystąpienie do prezesa Rady Ministrów, poszczególnych ministrów bądź niektórych innych organów państwa z postulatem podjęcia określonych działań. Na tym tle znacząco odmienny charakter miały dezyderaty uchwalane przez PET. W praktyce działalności tej Komisji dezyderat był wykorzystywany przede wszystkim jako instrument służący uzyskaniu informacji na temat zagadnienia objętego petycją, wyrażenia przez Radę Ministrów stanowiska w tym zakresie, jak również źródło informacji nt. ewentualnych prac legislacyjnych (bądź zamiarze ich podjęcia) w materii objętej petycją. W konsekwencji dezyderaty uchwalane przez PET odpowiadają bardziej instrumentowi uregulowanemu w art. 153 ust. $1 \mathrm{rS}$, tj. wystąpieniu przez komisję (prezydium komisji) do ministrów oraz kierowników naczelnych organów administracji rządowej o przedstawienie infor-

\footnotetext{
46 Vide np. przebieg posiedzenia komisji z 18 maja $2016 \mathrm{r}$.

${ }^{47} \mathrm{~W}$ jednym przypadku Komisja wystąpiła także z dezyderatem do głównego inspektora pracy.

${ }^{48}$ Żadna z działających w tym okresie komisji nadzwyczajnych, w tym komisji śledczych, nie wystąpiła $\mathrm{z}$ dezyderatem.

${ }^{49}$ Vide dane publikowane na stronie <www.sejm.gov.pl>, dotyczące liczby dezyderatów uchwalonych przez poszczególne komisje sejmowe.
} 
macji w sprawach stanowiących przedmiot prac Komisji. Zarysowana specyfika w zakresie posługiwania się dezyderatami przez PET nie prowadzi jednak do uznania, że przyjęta praktyka jest niewłaściwa.

Uchwalenie dezyderatu przez PET uznaje się za odrębny - w stosunku do wymienionych $\mathrm{w}$ art. $126 \mathrm{c}$ ust. $3 \mathrm{rS}$ - sposób załatwienia petycji ${ }^{50}$. W istocie jednak uchwalenie dezyderatu służy pozyskaniu przez Komisję niezbędnych informacji dotyczących stanu prawnego w sprawach objętych petycją oraz celowości - uwzględniając politykę realizowaną przez Radę Ministrów - wprowadzenia zmian legislacyjnych w danym obszarze. Po zapoznaniu się z odpowiedzią na dezyderat Komisja w zdecydowanej większości przypadków postanawiała o niepodjęciu inicjatywy ustawodawczej w zakresie wskazanym w petycji. Takie działanie materialnie odpowiada nieuwzględnieniu żądania stanowiącego przedmiot petycji. Także w wymiarze formalnym trudno uznać wystąpienie z dezyderatem (oraz przyjęcie odpowiedzi na dezyderat) za inny sposób załatwienia petycji niż jej nieuwzględnienie, skoro żądanie zawarte w petycji dotyczyło podjęcia zmian ustawodawczych, a nie wystąpienia z dezyderatem. W związku z tym należałoby postulować zmianę kwalifikacji stosowanej przez Komisję przy przedstawianiu informacji rocznej. Wystąpienie z dezyderatem, które nie skutkowało podjęciem inicjatywy ustawodawczej, powinno być wprost uznawane za rozstrzygnięcie polegające na nieuwzględnieniu petycji przez Komisję ${ }^{51}$.

Jednym z uprawnień przysługujących PET jest także możliwość wnoszenia poprawek do projektów ustaw rozpatrywanych przez Sejm. Uprawnienie to Komisja może realizować w odniesieniu do projektów ustaw, które zostały wniesione jako inicjatywa ustawodawcza tej Komisji bądź też gdy żądanie zawarte w petycji obejmuje postulat wniesienia poprawek do projektów ustaw stanowiących aktualnie przedmiot prac parlamentarnych. W okresie VIII kadencji Sejmu (do 31 grudnia 2018 r.) Komisja nie korzystała $\mathrm{z}$ tego uprawnienia.

2. Z punktu widzenia podmiotów występujących z petycją zasadniczym celem jest przekonanie PET o zasadności podjęcia inicjatywy ustawodawczej w danej sprawie (podjęcie innego działania wskazanego w petycji). Stąd wśród petycji skierowanych do Sejmu należy wyróżnić te, które zostały uwzględnione przez Komisję $\mathrm{i}$ ich następstwem było uruchomienie prac legislacyjnych. Liczba inicjatyw ustawodawczych podjętych w VIII kadencji Sejmu (do końca 2018 r.) jako rezultat wniesionych petycji jest znacząca. W 2015 r. Komisja w jednym przypadku postanowiła skorzystać z uprawnienia do wniesienia projektu ustawy (na pięć petycji rozpatrzonych ogółem w 2015 r.). W kolejnych latach liczba projektów ustaw wniesionych przez PET wynosiła: w 2016 r. - osiem projektów (na ogółem 102 rozpatrzone petycje); 2017 r. - 14 projektów (na ogółem 160 rozpatrzonych petycji); $2018 \mathrm{r}$. - 13 projektów (na ogółem 126 rozpatrzonych petycji). Udział uwzględnionych

\footnotetext{
${ }^{50}$ Vide informacja roczna o złożonych petycjach.

${ }^{51}$ Będzie to skutkować — statystycznie - kilkudziesięcioprocentowym wzrostem liczby petycji, w przypadku których Komisja faktycznie nie uwzględniła żądania zawartego w petycji.
} 
petycji w stosunku do ogólnej ich liczby wynosi zatem odpowiednio: 20\% (2015 r.), $8 \%$ (2016 r.), 10\% (2017 r.) i 10\% (2018 r.).

Uwzględniając petycję, Komisja powinna wystąpić z projektem ustawy, w którym możliwie wiernie zostałby zrealizowany cel wyrażony w petycji. Komisja nie musi jednak ograniczać się do przedmiotu oraz zakresu postulatów zaproponowanych w petycji. W razie uwzględnienia petycji PET może bowiem równocześnie wystąpić z inicjatywą zmiany innych przepisów ${ }^{52}$. Oczywiste jest natomiast, że zaproponowanie przez PET zmian o znacząco odmiennej treści w porównaniu z postulowanymi przez autora petycji należałoby kwalifikować jako niezgodne $\mathrm{z}$ istotą instytucji petycji.

3. Powierzenie rozpatrywania petycji kierowanych do Sejmu specjalnie powołanej w tym celu Komisji spowodowało, że proces ten stał się w istocie dwuetapowy. Mianowicie zgodnie z art. 126c ust. 3 pkt $1 \mathrm{rS}$ sposobem załatwienia petycji jest w szczególności wniesienie przez PET projektu ustawy realizującego postulaty zawarte w petycji. W istocie jednak takie działanie samo w sobie nie oznacza uwzględnienia żądania zawartego w petycji, skoro intencją podmiotu występującego z petycją jest wprowadzenie zmian przepisów rangi ustawowej, a nie samo zainicjowanie postępowania ustawodawczego w tym zakresie. Zmiana przepisów następuje dopiero wraz z zakończeniem procedury ustawodawczej, przy czym najważniejszym etapem pozostaje uchwalenie ustawy przez Sejm. Może zdarzyć się sytuacja, w której PET podejmie stosowną inicjatywę ustawodawczą realizującą postulaty zawarte w petycji, ale Sejm nie uchwali stosownej ustawy, ustawa zostanie uchwalona, ale w innym brzmieniu niż proponowane przez Komisję bądź też prace nad inicjatywą ustawodawczą — mimo nadania im biegu — faktycznie nie będą się toczyć. Sejm nie jest bowiem w żaden sposób zobligowany do uchwalenia ustawy zgodnej z żądaniem zawartym $w$ petycji, może też wprowadzić do niej zmiany niezgodne $\mathrm{z}$ intencją autora petycji, w tym zmiany niezgodne z propozycją wniesioną przez PET.

\section{TRYB ROZPATRYWANIA PETYCJI SKLADANYCH DO SEJMU}

1. Zgodnie z ustawą o petycjach, petycje wnosi się do organu władzy publicznej (art. 2 ust. 1). Organ, do którego została wniesiona petycja, jest zarazem organem właściwym do jej rozpatrzenia, a więc w szczególności rozstrzyga o sposobie jej załatwienia i ewentualnie - po uznaniu jej zasadności - podejmuje określone prawem działania. Tak więc rozpatrywanie petycji kierowanych do Sejmu, jak również rozstrzyganie o sposobie ich załatwienia leży w gestii Sejmu. Istotne odstępstwo w tym zakresie ustanowiono jednak w art. 9 ust. 1 ustawy o petycjach poprzez dopuszczenie, aby petycje wnoszone do Sejmu (dotyczy do również petycji wnoszonych do Senatu) były rozpatrywane przez organ wewnętrzny Izby, określony w przepisach regulaminu Sejmu (Senatu). Ratio legis art. 9 ust. 1 ustawy o petycjach nie budzi wątpliwości - nałożenie na Izbę działającą in pleno obowiązku rozpatrywania wnoszonych petycji z oczywistych względów stanowiłoby rozwiązanie skrajnie dysfunkcjonalne, nie tylko ze

\footnotetext{
${ }^{52}$ Confer m.in. posiedzenia Komisji z 6 lipca 2016 r. i 5 września 2016 r.
} 
względów czasowych. Realizując delegację zawartą w art. 9 ust. 1 ustawy o petycjach, w regulaminie Sejmu przewidziano utworzenie Komisji do Spraw Petycji (por. art. 18 ust. 1 pkt 1a rS), której zakres działania obejmuje rozpatrywanie petycji złożonych do Sejmu (por. pkt la załącznika do regulaminu Sejmu). Uzupełnieniem tego przepisu jest art. 126b ust. $1 \mathrm{rS}$, zgodnie z którym petycję złożoną do Sejmu marszałek kieruje w celu jej rozpatrzenia do $\mathrm{PET}^{53}$.

Trzeba zauważyć, że zgodnie z ustawą nie wymaga się, aby organem wewnętrznym Sejmu rozpatrującym petycje była komisja sejmowa. Jako organ właściwy w tych sprawach mógłby zostać wskazany także jeden z pozostałych organów Izby. Przekazanie omawianej kompetencji PET ma jednak ten istotny walor, że zapewnia jawność procedury rozpatrywania petycji, przy czym rozstrzygnięcie jest podejmowane $\mathrm{w}$ sposób kolegialny i pluralistyczny, po przeprowadzeniu dyskusji i wysłuchaniu opinii właściwych organów państwa. $Z$ tych też względów nie jest wskazane powierzenie rozpatrywania petycji organom jednoosobowym (marszałkowi), organowi zapewniającemu współdziałanie pomiędzy klubami (Konwent Seniorów) czy też wyposażonych w kompetencje o charakterze organizacyjnym (Prezydium Sejmu). Ponadto prace żadnego z tych trzech organów nie mają charakteru jawnego.

Alternatywnym wobec przyjętego w regulaminie Sejmu trybem rozpatrywania petycji byłoby kierowanie ich do właściwych komisji merytorycznych (resortowych). Wydaje się jednak, że nie ma podstaw do odstępowania od przyjętego aktualnie trybu rozstrzygania petycji, w którym kompetencję tę powierza się powołanej w tym celu Komisji do Spraw Petycji. Warto zauważyć, że analogiczne rozwiązanie funkcjonuje także w innych państwach (np. komisja ds. petycji w niemieckim Bundestagu) czy w Parlamencie Europejskim. Zgodnie z art. 9 ust. 1 ustawy kompetencje PET obejmują expressis verbis wyłącznie rozpatrywanie petycji, w praktyce jednak komisja rozstrzyga również o sposobie załatwienia petycji. Takie działanie znajduje zresztą wprost podstawy w przepisach regulaminu Sejmu (por. art. 126c ust. 1, zgodnie z którym rozpatrzenie petycji przez PET obejmuje m.in. rozstrzygnięcie w sprawie sposobu załatwienia petycji).

2. W ustawie o petycjach nie określono szczegółowo trybu rozpatrywania petycji. Z przepisów ustawy wynika jednak konieczność podjęcia przez podmiot, do którego została skierowana petycja, co najmniej trojakiego rodzaju czynności. Obejmują one: rozpatrzenie petycji (zapoznanie się z petycją, analiza jej zasadności itp.), podjęcie rozstrzygnięcia co do sposobu jej rozpatrzenia oraz zawiadomienie podmiotu występującego z petycją o sposobie jej rozpatrzenia („,załatwienia”). Nie wyczerpuje to jednak wszystkich koniecznych czynności składających się na tryb rozpatrzenia decyzji. Należy do nich zaliczyć m.in. ocenę formalnej dopuszczalności petycji, a więc np. kontrolę, czy petycja została wniesiona przez uprawniony do tego podmiot ${ }^{54}$, jak również ocenę, czy zawarte w niej żądania mieszczą się w zakresie działania adresata petycji.

${ }^{53}$ Ponadto — zgodnie z art. 10 ust. 1 pkt $8 \mathrm{~b}$ rS - marszałkowi Sejmu przyznano kompetencję do nadawania biegu petycjom złożonym do Sejmu.

${ }^{54}$ Stąd przykładowo nieodpuszczalne jest nadanie biegu petycji pochodzącej od podmiotu anonimowego. 
Nieco szerzej procedura rozpatrywania petycji przez Komisję została określona w regulaminie Sejmu. Zgodnie z art. 126c ust. $1 \mathrm{rS}$, rozpatrzenie petycji obejmuje przedstawienie petycji przez posła wyznaczonego przez prezydium Komisji, dyskusję oraz rozstrzygnięcie w sprawie sposobu załatwienia petycji. Komisja może się ponadto zwrócić do innych komisji o przedstawienie opinii ${ }^{55}$. W zakresie nieunormowanym w regulaminie Sejmu PET dysponuje względną swobodą co do określenia trybu rozpatrzenia petycji. W praktyce działania tej Komisji przyjęto, że w jej posiedzeniach uczestniczą przedstawiciele właściwych organów państwa (w szczególności ministerstw), w zakresie działania których mieszczą się sprawy objęte petycją. Podmioty te przedstawiają informacje dotyczące regulacji prawnej obowiązującej w materii objętej petycją, a często także swoje stanowisko co do zasadności jej przyjęcia bądź nieuwzględnienia. Stanowisko wyrażone przez stronę rządową nie jest wiążące dla Komisji. Jest ona uprawniona do podjęcia inicjatywy ustawodawczej realizującej postulaty zawarte w petycji także w razie negatywnej rekomendacji ze strony przedstawicieli organów administracji rządowej obecnych na posiedzeniu Komisji.

3. Częstotliwość prac PET determinuje przede wszystkim liczba petycji wniesionych do Sejmu. Istotną część prac Komisji stanowi także rozpatrywanie odpowiedzi na dezyderaty uchwalone przez PET. Zgodnie z dotychczasową praktyką, na jednym posiedzeniu komisji rozpatrywanych jest zazwyczaj od dwóch do czterech petycji. Równocześnie Komisja odbywała także posiedzenia, na których rozpatrywano wyłącznie odpowiedzi na dezyderaty.

W trakcie VIII kadencji Sejmu (do 31 grudnia 2018 r.) Komisja do Spraw Petycji odbyła łącznie 164 posiedzenia ${ }^{56}$. Analizując ten aspekt, wypada stwierdzić, że częstotliwość posiedzeń tej Komisji była wyższa niż średnia dla komisji sejmowych, choć zarazem występują komisje, w przypadku których liczba odbytych posiedzeń była znacząco wyższa. Według stanu na dzień 31 grudnia 2018 r. siedem komisji sejmowych odbyło w VIII kadencji Sejmu więcej posiedzeń niż PET, dwie komisje odbyły taką samą liczbę posiedzeń, natomiast 19 pozostałych komisji odbyło mniej posiedzeń niż PET $^{57}$.

$\mathrm{W}$ ustawie o petycjach nie zawarto wymogu jawności rozpatrywania petycji. Mimo to prace PET — podobnie jak pozostałych komisji sejmowych ${ }^{58}$ - są jawne. Posiedzenia są transmitowane za pośrednictwem strony internetowej Sejmu, ponadto następczo dostępny jest stenogram z posiedzenia Komisji wiernie odzwierciedlający

$55 \mathrm{Z}$ tego uprawnienia Komisja korzystała rzadko i jedynie w pierwszym roku swoich prac (confer posiedzenia komisji z: 13 stycznia 2016 r., 12 kwietnia 2016 r., 27 kwietnia 2016 r., 12 maja 2016 r. i 21 czerwca 2016 r.).

56 Trzeba wskazać, że nierzadko Komisja odbywała w tym samym dniu dwa posiedzenia, a incydentalnie nawet trzy.

${ }^{57}$ Dane te nie dotyczą — ze względu na ich czasowy charakter — komisji nadzwyczajnych oraz śledczych.

58 Wyjątek w tym zakresie stanowią komisje szczególne, jak Komisja do Spraw Służb Specjalnych, Komisja Odpowiedzialności Konstytucyjnej oraz komisje śledcze, które często odbywają posiedzenia zamknięte. 
jej przebieg (tzw. biuletyn), a także zapis video każdego posiedzenia. Umożliwia to osobom zainteresowanym, w tym zwłaszcza podmiotom występującym z petycjami, obserwowanie prac Komisji.

W obowiązujących przepisach nie rozstrzygnięto kwestii obecności podmiotu występującego z petycją na posiedzeniu PET. Trzeba zarazem zważyć, że rozpatrzenie petycji nie wymaga w żaden sposób obecności w trakcie prac Komisji podmiotu, który jest jej autorem. Uczestnictwo takiego podmiotu w posiedzeniu Komisji zależy zatem od uznania PET (w praktyce — prezydium bądź bezpośrednio przewodniczącego). Początkowo Komisja wyrażała ostrożne stanowisko w tej kwestii ${ }^{59}$, w późniejszym okresie udział tych osób w posiedzeniach był praktykowany. Dopuszczano także zabieranie przez te podmioty głosu $\mathrm{w}$ trakcie dyskusji. Jednocześnie należy odnotować, że stosunkowo częste były przypadki, kiedy w pracach Komisji uczestniczyli przedstawiciele stowarzyszeń, fundacji, związków pracodawców bądź przedsiębiorców występujących z petycją, natomiast raczej wyjątkowy był udział w posiedzeniach osób fizycznych będących autorami petycji.

W ramach Komisji do Spraw Petycji nie zostały powołane podkomisje. Oznacza to, że cała procedura rozpatrywania petycji, obejmująca przedstawienie wniesionej petycji przez posła referenta oraz dyskusję co do jej zasadności odbywa się na posiedzeniu PET. Gdyby jednak liczba wnoszonych petycji uległa znacznemu zwiększeniu w porównaniu ze stanem obecnym, dopuszczalnym rozwiązaniem byłoby przeniesienie szczegółowego rozpatrywania petycji na poziom podkomisji. W takim przypadku funkcją podkomisji byłoby przygotowanie wstępnej rekomendacji co do sposobu załatwienia poszczególnych petycji, natomiast ostateczne rozstrzygnięcie w tym zakresie podejmowałaby Komisja.

W odniesieniu do petycji wnoszonych do Sejmu została wprowadzona zasada kontynuacji (por. art. 126g rS). Tym samym, jeżeli postępowanie w sprawie petycji nie zostanie zakończone przed upływem kadencji, będzie ono kontynuowane w komisji działającej w Sejmie następnej kadencji. Zasada kontynuacji nie dotyczy jednak postępowania w sprawie projektów ustaw, które zostały wniesione w następstwie uwzględnienia petycji60.

Charakterystycznym elementem prawa do petycji jest brak możliwości wniesienia skargi do sądu na sposób załatwienia petycji (art. 13 ust. 2 ustawy o petycjach). Związane jest to $\mathrm{z}$ tym, że podjęcie przez organ działania w następstwie wniesienia petycji ma charakter uznaniowy. Natomiast skarga może być złożona w związku z kwestiami proceduralnymi dotyczącymi rozpatrywania petycji (np. uchybieniem terminu ${ }^{61}$ ).

59 Vide np. wypowiedź przewodniczącego Komisji na posiedzeniu Komisji z 2 grudnia 2015 r.

${ }^{60}$ Przepisy regulaminu Sejmu nie są jednak w tej kwestii w pełni jednoznaczne. Art. 126g rS, dotyczący zasady kontynuacji, odnosi się do „,postępowania w sprawie petycji”, które w szerokim znaczeniu obejmuje także działania podjęte w następstwie uwzględnienia petycji, a więc i proces ustawodawczy.

61 Wątpliwe jest natomiast, czy skarga mogłaby dotyczyć niedochowania trybu rozpatrywania petycji określonego w regulaminie Sejmu, a więc np. gdyby w procedurze rozpatrywania petycji nie została przeprowadzona dyskusja. 
4. Zgodnie $\mathrm{z}$ art. $63 \mathrm{zd} .2$ konstytucji, tryb rozpatrywania petycji określono $\mathrm{w}$ ustawie. Przepis ten nie zawiera zastrzeżenia, że w przypadku petycji wnoszonych do Sejmu bądź Senatu określenie zasad ich rozpatrywania następuje w regulaminach izb, w ramach przysługującej tym organom autonomii ${ }^{62}$. Stąd należałoby uznać, że w regulaminie Sejmu (i analogicznie w regulaminie Senatu) nie mogą zostać unormowane kwestie związane z trybem rozpatrywania petycji. Zasada ta nie jest jednak w pełni realizowana, jeśli uwzględnić brzmienie art. 126c ust. $1 \mathrm{rS}$ („,Rozpatrzenie petycji obejmuje przedstawienie petycji przez posła wyznaczonego przez prezydium Komisji, dyskusję oraz rozstrzygnięcie w sprawie sposobu załatwienia petycji”). Nie negując merytorycznej zasadności wskazanego przepisu, należy uznać, że wobec jednoznacznego brzmienia art. $63 \mathrm{zd} .2$ konstytucji zagadnienie to powinno zostać uregulowane w ustawie o petycjach, a nie w regulaminie Sejmu ${ }^{63}$.

5. Ustawodawca przewidział trzymiesięczny termin na rozpatrzenie petycji (por. art. 10 ust. 1 ustawy) ${ }^{64}$. Mając na względzie dyrektywę lege non distinguente, należy uznać, że okres ten obejmuje także podjęcie przez organ będący adresatem petycji postulowanego w niej działania. W przypadku petycji kierowanych do Sejmu termin ten traktowany jest jednak w sposób szczególny, ponieważ nie jest wliczany do niego czas, w którym następuje realizacja żądania zawartego w petycji. Jak już bowiem wskazywano, uwzględnienie petycji przez Komisję nie jest równoznaczne z załatwieniem petycji. Zdecydowana większość petycji kierowanych do Sejmu zawiera żądanie zmiany przepisów rangi ustawowej. PET nie dysponuje jednak - co oczywiste kompetencjami w zakresie zmiany prawa, jej uprawnienia ograniczają się wyłącznie do wystąpienia z inicjatywą ustawodawczą. W przypadku petycji kierowanych do Sejmu termin trzymiesięczny liczony jest zatem tylko dla postępowania w ramach Komisji, w tym czasie może ona w szczególności podjąć uchwałę o wystąpieniu z inicjatywą ustawodawczą stanowiącą realizację petycji. Natomiast uchwalenie odpowiednich zmian normatywnych — co pozostaje w gestii Sejmu — nie jest objęte tym terminem.

Należy ponadto odnotować, że w toku rozpatrywania wniesionych petycji Komisja wielokrotnie występowała z dezyderatami w celu uzyskania dodatkowych informacji na temat spraw objętych petycją. Na tym tle powstaje wątpliwość, czy trzymiesięczny termin obejmuje jedynie samo rozpatrzenie przez PET petycji i towarzyszący jej

${ }^{62}$ Taki przepis został wprowadzony w odniesieniu do trybu rozpatrywania wniosków o udzielenie informacji publicznej. Zgodnie z art. 61 ust. 4 konstytucji tryb udzielania informacji o działalności organów władzy publicznej oraz osób pełniących funkcje publiczne określają ustawy, a w odniesieniu do Sejmu i Senatu — regulaminy izb.

${ }^{63}$ Trzeba jednak zauważyć, że w piśmiennictwie zakaz regulowania tego typu spraw na poziomie regulaminu Sejmu nie jest uznawany za bezwzględny. Wskazuje się bowiem, że ustawą można przekazywać unormowanie spraw związanych z rozpatrywaniem petycji do regulaminu, o ile nie są to sprawy „,szczególnie istotne dla obywateli” (vide W. Sokolewicz, K. Wojtyczek, uwaga 9 do art. 63 [w:] Konstytucja Rzeczypospolitej Polskiej. Komentarz, t. II, red. L. Garlicki, M. Zubik, Warszawa 2016).

${ }^{64}$ Zgodnie z art. 10 ust. 3 ustawy dopuszczono wydłużenie tego terminu o dalsze trzy miesiące, w przypadku wystąpienia okoliczności niezależnych od podmiotu rozpatrującego petycję, uniemożliwiających jej rozpatrzenie w terminie. 
wniosek o wystąpienie przez Komisję z dezyderatem, czy także przygotowanie przez właściwy organ odpowiedzi na dezyderat i rozpatrzenie tej odpowiedzi przez Komisję. W praktyce w działalności Komisji przyjęto pierwszą z przedstawionych interpretacji.

\section{PODSUMOWANIE}

Podsumowując dotychczasowe doświadczenia związane z funkcjonowaniem sejmowej Komisji do Spraw Petycji, należy zwrócić uwagę na następujące aspekty, które charakteryzują jej prace oraz — szerzej — petycje wnoszone do Sejmu.

1. Powołanie PET stanowi bez wątpienia realizację przez Sejm obowiązku wynikającego z art. 63 konstytucji, przyznającego obywatelom (podmiotom podobnym) prawo do wnoszenia petycji do organów władz publicznych. Przy czym w przypadku parlamentu rozpatrywanie petycji zostało powierzone nie bezpośrednio adresatowi petycji (Sejmowi), tylko jego organowi wewnętrznemu, co jest zgodne z mechanizmami funkcjonowania współczesnego parlamentu. Trzeba zarazem wyrazić rozczarowanie, że ustawodawca zdecydował się na urealnienie konstytucyjnego prawa do petycji dopiero po 17 latach od wejścia w życie obecnej konstytucji.

2. Przedmiotem wnoszonych do Sejmu petycji rozpatrywanych przez PET były niemal wyłącznie postulaty zmiany obowiązujących przepisów. Petycje nie dotyczyły natomiast podejmowania innych działań mieszczących się w zakresie kompetencji Sejmu. Taki stan wydaje się naturalny, jeśli zważyć, że podstawową funkcją Sejmu jako organu władzy ustawodawczej jest stanowienie prawa.

3. Komisja przyjęła swoiste ograniczenie ze względu na rodzaj spraw, w odniesieniu do których podejmowała inicjatywę ustawodawczą w następstwie uwzględnienia petycji. Uznano, że zmiany legislacyjne inicjowane przez PET powinny mieć charakter jednostkowy, a więc dotyczyć pojedynczych, konkretnych rozwiązań. Odpowiednio do tego wszystkie inicjatywy, jakie Komisja podejmowała, miały charakter nowelizujący (przy czym chodziło o drobne zmiany), odstępowano natomiast od inicjatyw obejmujących bardziej kompleksowe zmiany w ustawodawstwie.

4. Realizacja prawa petycji przez Sejm z pewnością nie może być postrzegana w kontekście liczby spraw, w których Komisja postanowiła podjąć inicjatywę ustawodawczą. Nie można jednak nie zauważyć, że liczba ta jest znaczna. W okresie od listopada 2015 r. do grudnia 2018 r. Komisja wystąpiła łącznie z 27 projektami ustaw $^{65}$, z czego 11 stało się do końca 2018 r. obowiązującym prawem.

5. Działalność PET w istotnym stopniu stanowi realizację funkcji kontrolnej przysługującej Sejmowi. Nie jest to wprawdzie samodzielnym celem działania Komisji, ale zarazem pozyskiwanie informacji od organów administracji rządowej jest konieczne do podejmowania przez Komisję decyzji co do sposobu rozstrzygnięcia petycji. Formalnym potwierdzeniem tego faktu jest liczba dezyderatów, z którymi wystąpiła Komisja. Odpowiedzi na dezyderaty są rozpatrywane na posiedzeniach Komisji, przez co stanowią one źródło informacji o działalności Rady Ministrów w poszczególnych obszarach.

${ }^{65}$ W jednym przypadku Komisja wycofała złożony uprzednio projekt ustawy. 
6. Szczególną cechą PET jest to, że nie ma ona charakteru resortowego. Wynika stąd - w znacznym stopniu - odmienna perspektywa prac tej komisji w porównaniu z komisjami resortowymi. PET podejmuje sprawy jednostkowe, a zarazem takie, które są pomijane w inicjatywach legislacyjnych Rady Ministrów lub w których zmiany normatywne nie są według Rady Ministrów zasadne. Chodzi przy tym o sprawy istotne z perspektywy pojedynczych osób, które występują z petycjami.

7. Znaczna jest liczba przypadków, kiedy ten sam podmiot wnosi petycje o tożsamej treści równolegle do różnych organów (Sejm, Senat, Rada Ministrów, poszczególni ministrowie). Zdarzało się także, że petycja o tej samej treści była równolegle rozpatrywana przez PET oraz przez działającą w Senacie Komisję Praw Człowieka, Praworządności i Petycji. Organy będące adresatami petycji rozpatrują je odrębnie od siebie i podejmują $\mathrm{w}$ tym względzie samodzielne rozstrzygnięcia. Jeśli jeden z organów podjął już działania zmierzające do realizacji postulatu wyrażonego w petycji (np. toczą się prace nad podjęciem inicjatywy ustawodawczej), jest to podstawą do nieuwzględnienia tej samej petycji przez inny organ.

8. Działalność PET VIII kadencji ukształtowała praktykę, która bez wątpienia zasługuje na kontynuację i utrwalenie w toku kolejnych kadencji Sejmu. Pewien niedosyt, jeśli chodzi o działalność Komisji, można odczuwać w związku z tym, że w jej pracach aktywnie uczestniczyła grupa zaledwie 5-7 posłów. Tylko z tej grupy wywodzili się referenci poszczególnych spraw, jak również osoby zabierające głos w dyskusji. Nie można wykluczyć, że aktywne włączenie się w prace większej grupy posłów umożliwiałoby w niektórych przypadkach bardziej pogłębioną refleksję co do postulatów podnoszonych w petycjach. Można bowiem wyrazić subiektywną ocenę, że niektóre spośród petycji nieuwzględnionych przez Komisję zasługiwały na odmienne potraktowanie (np. petycja penalizująca niszczenie elewacji poprzez umieszczanie na nich graffiti $\left.{ }^{66}\right)$.

BIBLIOGRAFIA

Czarny P., Opinia prawna w sprawie dopuszczalności składania petycji przez jednostki samorządu terytorialnego, „Zeszyty Prawnicze BAS” 2017, nr 3.

Działocha K., Prawo petycji w obowiazujacym ustawodawstwie i proponowane kierunki zmian, [w:] Prawo petycji w ustawodawstwie polskim, „Opinie i Ekspertyzy” 2008, nr 85.

Florczak-Wątor M., komentarz do art. 63, [w:] Konstytucja RP. Komentarz, t. I, art. 1-86, red. M. Safjan, L. Bosek, C.H. Beck, Warszawa 2016.

Gajewski S., Jakubowski A., Petycje, skargi i wnioski. Dziat VIII Kodeksu postępowania administracyjnego. Ustawa o petycjach. Komentarz, C.H. Beck, Warszawa 2015.

Galster J., Lis-Staranowicz D., Zakres podmiotowy prawa do petycji w Polsce $i$ w Unii Europejskiej. Przyczynek do dyskusji, „Przegląd Sejmowy” 2018, nr 3.

Gierach E., Chybalski P., Postepowanie w sprawie petycji w Sejmie - prawo i praktyka, [w:] Skargi, wnioski i petycje - powszechne środki ochrony prawnej, red. M. Błachucki, G. Sibiga, Presscom, Wrocław 2017.

${ }^{66}$ Petycja BKSP-145-311/17. 
Masternak-Kubiak M., Kuczma P., Prawo petycji jako publiczne prawo podmiotowe (aspekt podmiotowy i przedmiotowy), [w:] Teoretyczne i praktyczne aspekty realizacji prawa petycji, red. R. Balicki, M. Jabłoński, Prawnicza i Ekonomiczna Biblioteka Cyfrowa, Wrocław 2015.

Orłowski W., Konstytucyjne uwarunkowania prawa petycji, [w:] Prawo petycji w ustawodawstwie polskim, „Opinie i Ekspertyzy” 2008, nr 85.

Orłowski W., Prawo składania petycji, wniosków i skarg, [w:] Wolności i prawa polityczne, red. W. Skrzydło, Kantor Wydawniczy Zakamycze, Kraków 2002.

Ożóg M., Uregulowanie instytucji petycji w ustawie z dnia 11 lipca 2014 r. o petycjach, „Przegląd Sejmowy" 2015, nr 5.

Piskorz-Ryń A., Wyporska-Frankiewicz J., Wykorzystywanie prawa do petycji w sposób niezgodny z jego celem. Zagadnienia wybrane, [w:] Skargi, wnioski i petycje - powszechne środki ochrony prawnej, red. M. Błachucki, G. Sibiga, Presscom, Wrocław 2017.

Rytel-Warzocha, Instytucja petycji w Polsce oraz w krajach europejskich - stan obecny i perspektywy, „Opinie i Analizy” OE-238, Kancelaria Senatu, Warszawa 2015.

Rzucidło J., Prawo petycji w działalności Senatu i Sejmu RP w latach 2010-2015, [w:] Teoretyczne i praktyczne aspekty realizacji prawa petycji, red. R. Balicki, M. Jabłoński, Prawnicza i Ekonomiczna Biblioteka Cyfrowa, Wrocław 2015.

Sarnecki P., Prawo konstytucyjne RP, C.H. Beck, Warszawa 2014.

Sokolewicz W., Wojtyczek K., uwaga 9 do art. 63 [w:] Konstytucja Rzeczypospolitej Polskiej. Komentarz, t. II, red. L. Garlicki, M. Zubik, Wydawawnictwo Sejmowe, Warszawa 2016.

Wójcicka E., Prawo petycji w Rzeczypospolitej Polskiej, Wydawnictwo Sejmowe, Warszawa 2015. 